\title{
Potential of Water Hyacinth (Eichhornia crassipes) as Compost and its Effect on Soil and Plant Properties: A Review
}

\author{
S.L. Rasmiya Begum¹, S.M.M.S. Himaya1', S.M.M.S. Afreen²
}

10.18805/ag.R-184

\begin{abstract}
Water hyacinth, the devastating weed grows in water bodies either naturally or as a result of human interference, is considered as threat to environment due to its negative effects on aquatic ecosystems. To alleviate its negative impact utilization of those become as better mean in recent decades. As such, water hyacinth is known to has potential to be utilized as nutrient source via composting, all most all types of composting techniques are applicable in preparation of compost from water hyacinth. Being an organic source, water hyacinth helps build up soil organic matter, in turn play vital role in the enrichment of the soil physical, chemical and biological properties. Aggregation of soil particles, porosity, density, water holding capacity, nutrient availability, cation exchange capacity, pH, soil microorganism are the soil properties reported to improve with water hyacinth compost application. Moreover, water hyacinth compost seems to be far better than the animal manures in improvement of soil properties. As a result, water hyacinth compost shows magnificent effect of plant agronomic growth parameters such as germination percentage, number of leaves, leaf area index, plant height, length of shoot and root, root: shoot ratio, biomass content as well as yield parameters. However, utilization of water hyacinth has few challenges like difficulties in harvesting, chance for heavy metal accumulation, hardness during decomposition, less awareness. Properly managed water hyacinth compost would serve as an alternative for inorganic nutrient sources in future thus indirectly the threat caused by this aquatic weed on environmental would become minimum.
\end{abstract}

Key words: Compost, Growth attributes, Organic matter, Soil properties, Water hyacinth.

Water hyacinth is a free-floating perennial aquatic weed native to tropical and sub-tropical South America (Rodrigues et al. 2014). Even it is originated in the Amazon Basin and has now spread to over 80 countries (Jafari, 2010). It is abundantly present in almost all types of wetlands vary from small fish ponds to big riverine lakes. Water hyacinth has been recognized as the most harmful aquatic weed in the world due to its negative effects on people's livelihoods and wetland ecosystems (Wilson, 2005). Water hyacinth dramatically impacts water flow, blocks sunlight from reaching native aquatic plants and starves the water of oxygen, often smother aquatic life by deoxygenating the water and it reduces nutrients for young fish in sheltered bays (Sindhu et al. 2017). Water hyacinth also interferes with water treatment, irrigation and water supply (Opande et al. 2004). The plants also create a prime habitat for mosquitos and a species of snail, classically causes diseases. It has blocked supply intakes for the hydroelectric plant, interrupting electrical power for entire cities. The weed also interrupts local subsistence fishing, blocking access to the beaches. Therefore, the control of this devastating weed receives attention and many efforts have been made to control these weeds through chemical, physical and biological methods. However, control of the weed has met with little success (Abdelsabour, 2010), in turn a need for an alternative mean of its control arouse. So that, rather than destruction make them useful was sought as better mean of control.

Since water hyacinth is being an organic manure, its effects in combating soil quality issues is well addressed.
1Department of Biosystems Technology, Faculty of Technology, South Eastern University of Sri Lanka, University Park, Oluvil, Ampara, Sri Lanka.

${ }^{2}$ Department of Agricultural Chemistry, Faculty of Agriculture, Eastern University, Sri Lanka.

Corresponding Author: S.L. Rasmiya Begum, Department of Biosystems Technology, Faculty of Technology, South Eastern University of Sri Lanka, University Park, Oluvil, Ampara, Sri Lanka. Email: imara@seu.ac.lk

How to cite this article: Rasmiya Begum, S.L., Himaya, S.M.M.S. and Afreen, S.M.M.S. (2021). Potential of Water Hyacinth (Eichhornia crassipes) as Compost and its Effect on Soil and Plant Properties: A Review. Agricultural Reviews. DOI: 10.18805/ag.R-184.

Submitted: 19-12-2020 Accepted: 16-10-2021 Online: 09-11-2021

Water hyacinth helps to combat organic matter decline and soil erosion (Lickacz and Penny, 2001). Hence, water hyacinth is well known for its potential as nutrient replenisher either as green manure or compost. Water hyacinth is increasingly being used as a nutrient supplier as composted material (Malik, 2007). From the literature, it is clear that water hyacinth has potential to prepare compost by means of almost all the composting techniques and serve as a mean in soil fertility improvement. Composting of biodegradable water hyacinth puts back the nutrients into the soil through recycling them and helps to optimize nutrient management. Bacteria, actinomycetes, streptomycetes and fungi are among the mesophilic, thermo-tolerant microorganisms that 
have been found in composting of various waste materials (Hassen et al. 2001; Ryckeboer et al. 2003). It is capable of accumulating very high concentration of primary macro nutrients $\mathrm{N}, \mathrm{P}$ and $\mathrm{K}$ (Balasubramanian, 2011) and could serve as source of these nutrients in fertility management upon decomposition (Kwabiah et al. 2003; Wasonga, 2008). Furthermore, water hyacinth has a high potential to supply nitrogen as it can store up to $3.2 \%$ in its dry mass and it generally has a carbon to nitrogen ratio $(\mathrm{C} / \mathrm{N})$ of around 8 to 15 (Khan and Sarwar, 2002; Gunnarsson and Petersen, 2007). Water hyacinth has not only found effective in soil fertility enhancement, it improves soil properties and health in turn enhances crop yield when applied as green manure or compost (Woomer et al. 2000; Gupta et al. 2004). In this review we briefly discuss the potential of water hyacinth as composting material and its effect on plant and soil. This would be utilized in future researches where control of water hyacinth till being a problem and composting is not practiced also it will be valuable teaching tool in the world of academia for control measures of water hyacinth.

\section{Classification and morphology of water hyacinth}

Water hyacinth is a free-floating perennial hydrophyte. It is a highly competitive plant that is capable of rapid growth and spread so that is called "menace and nuisance" to the ecosystems. The classification of water hyacinth follows as below:

Division: Spermatophyta

Sub Division: Angiospermae

Class: Monocotyledonae

Series: Coronariae

Family: Pontederiaceae

Genus: Eichhornia

Species: E. crassipes (Mart.) Solms

\section{Morphological description}

The leaves are broad, thick, glossy and ovate and float above the water surface (Fig 1). They have long, spongy and bulbous stalks. The feathery, freely hanging roots are purpleblack. It tolerates annual temperatures ranging from $28-30^{\circ} \mathrm{C}$ (Burton et al. 2010) and its $\mathrm{pH}$ tolerance is estimated at 5.0 to 7.5. The 'beautiful blue devil' water hyacinth, grows rapidly as a dense green mat over stagnant water bodies such as lakes, streams, ponds, waterways, ditches and backwaters and is recognized by its lavender flowers and shinning bright leaves.

\section{Water hyacinth as compost and its effect on soil properties}

Composting is a natural process which involves the aerobic biological decomposition of organic matter from the biodegradable wastes using microbes under controlled conditions, resulting a final product containing stabilized carbon, nitrogen and other nutrients in the organic fraction, the stability depending on the compost maturity (Singh and Sharma, 2002; Chang and Chen, 2010). Similar to other organic manures, water hyacinth has potential to prepare compost with different methods (Table 1). The water hyacinth compost was found better than the town compost and farm yard manure in terms of nutrient contents such as $\mathrm{N}, \mathrm{P}_{2} \mathrm{O}_{5}$, $\mathrm{K}_{2} \mathrm{O}$ and $\mathrm{C}: \mathrm{N}$, it is four times richer than farm yard manure (Basak, 1948). Table 2 presents the nutritional composition of water hyacinth-based compost. Hence, the quality of compost may vary with raw materials, composting conditions (temperature, moisture and aeration), climate, method of composting etc (Table 1). Easily decomposable water hyacinth compost contributes buildup of organic matter in the soil and thereby affects soil physical as well as chemical parameters like the other organic composts. Balasubramanian et al. (2013) reported that the soil organic matter ranged from $0.64-3.57 \%$ in soil mulched with water hyacinth throughout cropping period irrespective of soil depth and days. Organic matter in the form of water hyacinthbased compost influences soil physical properties inclusive of aggregate formation, porosity, bulk density, water holding capacity, cation exchange capacity.

\section{Response on soil aggregation}

It is simply known as process of sticking of primary soil particles to each other more tenaciously than adjacent particles. Organic matter favours aggregation in soil as they tend to release gum like materials during decomposition process which helps in binding of particles. Water hyacinth as being an organic matter, addition of it into the soil enhances aggregate formation, primarily of state as well as degree of aggregation that varies with application rate.

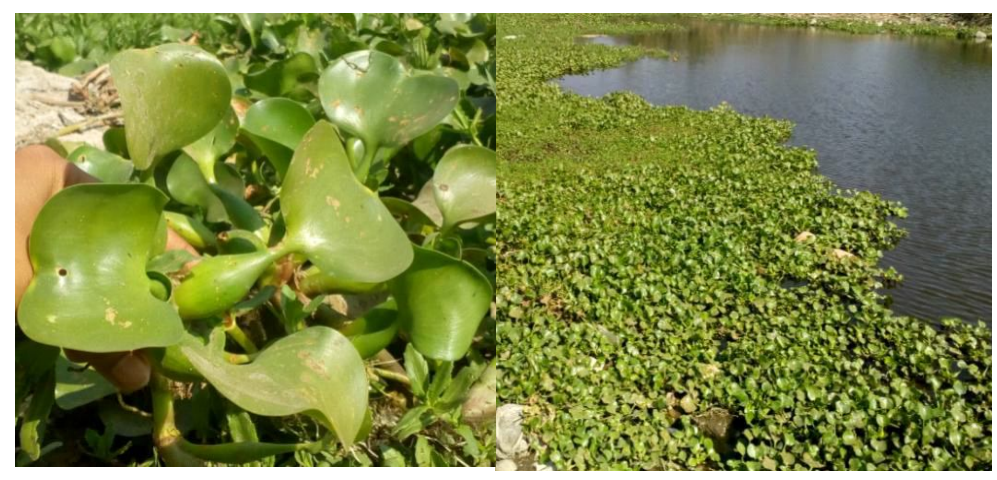

Fig 1: Water hyacinth in natural water bodies. 


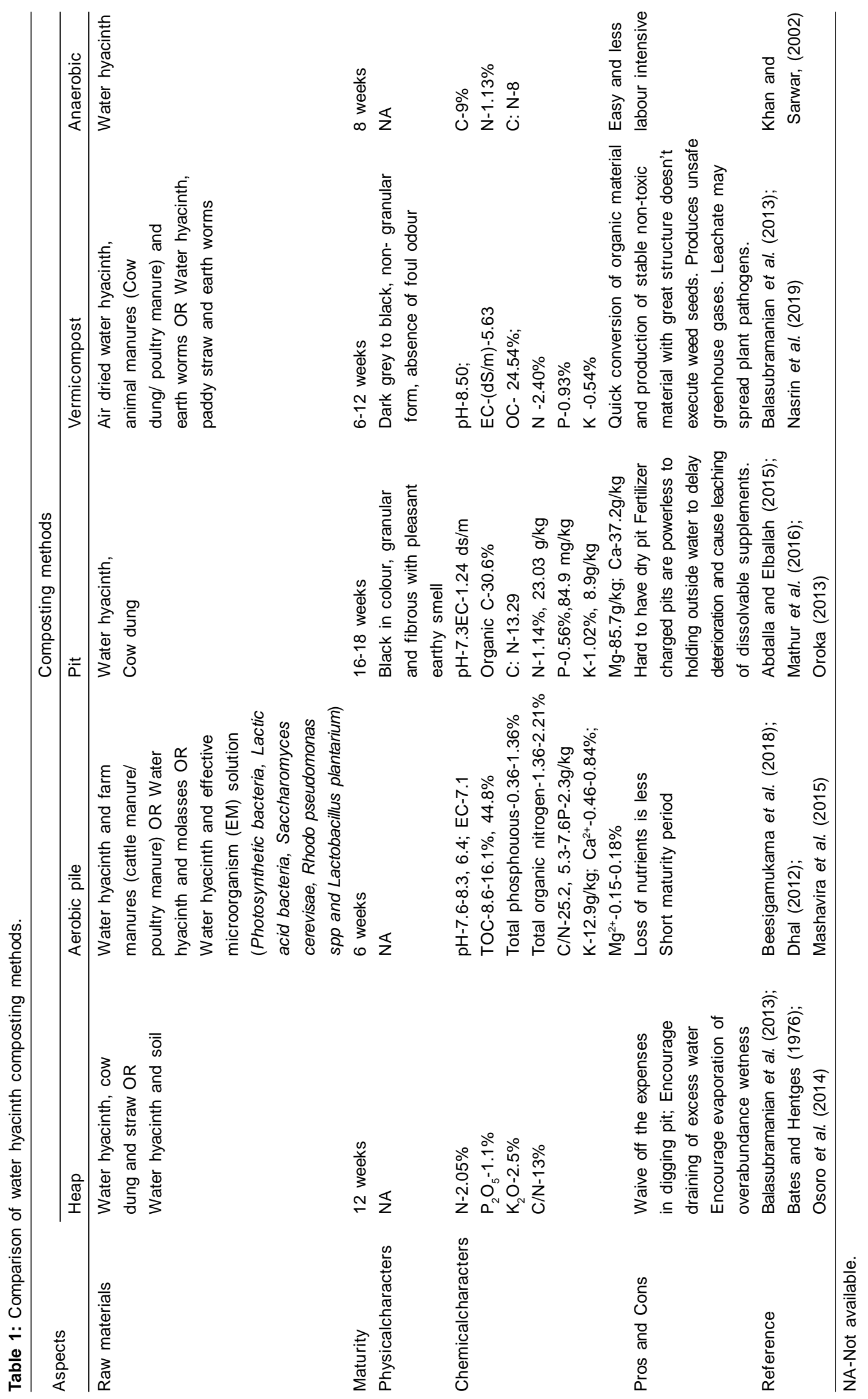


Table 2: Nutritional composition of Water hyacinth-based composts.

\begin{tabular}{lc}
\hline Nutrition composition & Water hyacinth compost \\
\hline TON (\%) & 1.36 \\
TOC (\%) & $10-12$ \\
Total P (\%) & $0.028-0.38$ \\
pH & $7.6-8.4$ \\
K (\%) & 1.1 \\
C: $\mathrm{N}$ & $7.6-9.3$
\end{tabular}

Modified from (Naluyange, 2014) (Beesigamukama, 2018).

TON=Total organic nitrogen, $\mathrm{TOC}=$ Total organic carbon .

Higher organic matter with increasing amount of water hyacinth higher the state and degree of aggregation (Martin et al., 1955). Degree of aggregation was $27 \%$ higher than control when $1000 \mathrm{~g}$ of water hyacinth was used per pot in sandy loam soil (Khan and Sarwar, 2002). Hence, Rashid and Iftekhar (1992) additionally detailed that the degree of aggregation of soil expanded because of water hyacinth fertilizer.

\section{Response on soil porosity and bulk density}

Greater amount of organic matter deposition through water hyacinth-based compost improves aggregation process between soil primary particles into microaggregates through cementing agents (Polysaccharide gums) produced by soil bacteria upon the decomposition of added organic matter and further into macroaggregates by growth of fungal and actinomycete hyphae growing over the soil particles. All these aggregation process increase the total porosity in soil. As bulk density is inversely related to total porosity water hyacinth-based compost decreases bulk density in soils. The aggregation processes may have reduced soil bulk density and increased porosity with the soil having greater capacity for water retention and transmission (Goldhamer et al. 1994; Sultani et al. 2007). An increase in total porosity and corresponding decrease in bulk density than untreated plots were noted by (Oroka, 2013) in sole cassava and cassava-groundnut intercrop with application of vermicompost prepared from mixture water hyacinth and farm manure. Wanas (2006) observed $15 \%$ and $12.3 \%$ reduction in soil bulk density under shallow and deep ploughing respectively using water hyacinth compost when compared to control without organic amendments. Average bulk density values were 1.20 and $1.22 \mathrm{gm}^{-3}$ for shallow and deep ploughing depths respectively. The study further noted increased total porosity of $12.41 \%$ and $10.49 \%$ for the same ploughing depths. The decline in soil bulk density with a related expansion in porosity under water hyacinthbased manures might be because of more significant measure of organic matter deposition (Haynes, 2000; Agbede et al. 2008).

\section{Response on soil water holding capacity}

Water hyacinth compost improves water holding capacity of soil in two ways. Firstly, water hyacinth as direct organic particles improve water holding capacity through their higher surface area and potential for adsorption of water molecules. Secondly, by influencing soil physical properties especially porosity and bulk density improve water holding capacity (Rashid and Iftekhar, 1992; Khan and Sarwar, 2002). As water hyacinth compost favours aggregation, porosity get increased either within the aggregates (micro pores) or between the aggregates (macro pores). With greater amount of micro pores water holding capacity increases. Water holding capacity of sandy loam soil increased from 8.21 to $10.16 \%$ with addition of $1000 \mathrm{~g}$ of water hyacinth compost (Khan and Sarwar, 2002). Similarly, Vidya and Girish (2014) also reported an increase in water holding capacity from 52.04 to 57.31 when garden soil is mixed with equal proportion of water hyacinth compost.

\section{Response on soil cation exchange capacity and $\mathbf{p H}$}

Cation exchange capacity (CEC) is the total capacity of a soil to hold exchangeable cations. Compost prepared from water hyacinth has marked effect on cation exchange capacity of soil due to buildup of organic matter from water hyacinth compost. Organic matter components of soil have negatively charged surfaces onto which exchangeable cations are adsorbed. With decomposition of compost, the exchangeable cation nutrients get released and become available for exchange with colloidal surface.

Cation exchange capacity was higher in water hyacinth compost treated sandy loam soil than the untreated soil and higher water hyacinth content higher cation exchange capacity (Khan and Sarwar, 2002). Abdalla and Elballah (2015) reported an increase in cation exchange capacity from 22.95 to 23.78 at a depth of $0-30 \mathrm{~cm}$. As exchangeable basic cations are exchanged and get adsorbed to organic matter and soil surfaces, acidic cations are released to soil solution and soil become acidic, receives less $\mathrm{pH}$ values. Abdalla and Elballah (2015) reported a decline in $\mathrm{pH}$. In vice versa an increase in $\mathrm{pH}$ also was observed with addition of water hyacinth (Khan and Sarwar, 2002; Vidya and Girish, 2014). This might be due to precipitation of some cations, depletion of carbon source as composting proceeds for bacterial and fungal breakdown of recalcitrant materials of water hyacinth.

\section{Response on soil mineral nutrients}

Application of water hyacinth increase the mineral nutrients content in the soil as these nutrients ae considerably high in fresh water hyacinth. When compost prepared from this nutrient rich organic matter these nutrients get released into the soil upon decomposition process and become available for plant uptake. Comparatively higher total nitrogen and available phosphorous were recorded when soil is mulched with water hyacinth compost that control plots (Balasubramanian et al. 2013). Availability of nutrients vary with soil depth, times of application, decomposition and mineralization rate etc. With respect to nitrogen, water hyacinth compost application increased nitrate nitrogen 
Potential of Water Hyacinth (Eichhornia crassipes) as Compost and its Effect on Soil and Plant Properties: A Review

$\left(\mathrm{NO}^{3-} \mathrm{N}\right)$, ammonium nitrogen $\left(\mathrm{NH}^{4+} \mathrm{N}\right)$ and total mineral nitrogen before sowing first main crop and even after harvesting of the crop as well and it was found to be two folds higher than untreated plots (Abdalla and Elballah, 2015). Further, they found that compost made from water hyacinth applied at 10 tons/hectare increased the mineral nutrients such as $\mathrm{Ca}, \mathrm{Mg}, \mathrm{Na}, \mathrm{K}, \mathrm{P}$, total mineral nitrogen.

Moreover, Table 3 shows the effects of widely applied animal manures like cow dung and poultry manure along with water hyacinth manure compare to control on key soil properties. It reveals that, in overall, organic manures regardless of type improves soil properties. Of which water hyacinth-based manures found to be better than the animal manures as it has greater effect on soil properties referring to organic carbon, $\mathrm{pH}, \mathrm{CEC}$ and primary soil nutrients $(\mathrm{N}, \mathrm{P}$ and $\mathrm{K}$ ). This might be due to inherent composition of water hyacinth. Hence, the effects vary with application rate and soil texture.

\section{Effects of water hyacinth compost on plant growth}

Water hyacinth-based compost application influences several growth parameters. Germination percentage, number of leaves, leaf area index, plant height, length of shoot and root, root: shoot ratio, biomass content, collar root diameter are some example for the growth attributes. In general, from the experiments it has been found that compost application increases the mean values of abovementioned attributes either significantly or non-significantly than control. It's because of the availability of essential mineral nutrients required for plant growth and development. Nitrogen and phosphorous are the primary elements needed by plants. Phosphorus is important in root growth and development and therefore nutrient uptake; while nitrogen is important in chlorophyll formation for photosynthesis and protein formation hence fast growth (Hawkesford et al. 2012). These nutrients get released through mineralization process of organic matter content which improves moisture retention capacity of soil as well and thereby with improved dissolution of those released nutrients become readily available for plant uptake. Further, higher microbes in compost improves soil aeration and enhance uptake of dissolved nutrients by the roots and better growth and development of crops (Olupot, 2004). Effects of water hyacinth compost on growth parameters are indicated in the Table 4 . These effects vary with rate of compost application; higher application rate higher the growth attributes, co-composting with other materials, stage of crop, soil condition. As compost releases nutrients slowly but steadily compare to inorganic fertilizers, effect of compost on growth attributes can be seen at later stages of growth rather than early stages. For example, 3.35 leaf area index was recorded in maize at $10^{\text {th }}$ week by Beesigamukama et al. (2018) while it is 2.19 only at $6^{\text {th }}$ weeks when water hyacinth compost applied. Higher shoot dry weight and plant height of $4.24 \mathrm{~g}$ and $26.17 \mathrm{~cm}$ respectively were observed 45 days after emergence in maize than that of $0.73 \mathrm{~g}$ and $15.57 \mathrm{~cm}$ respectively at $15^{\text {th }}$ day with application of water hyacinth compost prepared with cattle manure and these were comparatively less when the compost is co-composted with effective microorganism $(0.68$ $\mathrm{g}$ and $16.32 \mathrm{~cm}$ ). Though, compost application has positive impacts for many of the growth attributes, negative impacts also possible especially on number of days to maturity. Mashavira et al. (2015) mentioned that water hyacinth compost applied at a rate of $74.1 \mathrm{t} \mathrm{ha}^{-1}$ delays the maturity of tomato fruits as increased $\mathrm{N}$ supply increases plant growth and promotes vegetative growth at the expense of fruiting and maturing (Azam, 1985).

\section{Effects of water hyacinth compost on yield}

Application of water hyacinth has magnificent effect on yield of various crops. Several studies indicated that yield components like panicles/pot, 100 seed weight were significantly increased with application of water hyacinth compost either alone or fortified with nutrient rich locally available sources. Khan and Sarwar, 2002 notified an increase in yield of rice from $19.7 \%$ to 22.3 with application of water hyacinth compost at a rate of $1000 \mathrm{~g}$ per pot. Osoro et al. (2014) stated that weight of 100 seeds of common bean ranged from 41.5-50.2 in three farmers' fields that lie within the Lake Victoria Basin where no history of inorganic

Table 3: Effect of organic manures on soil properties.

\begin{tabular}{|c|c|c|c|c|c|c|c|c|c|}
\hline $\begin{array}{l}\text { Organic } \\
\text { manures }\end{array}$ & $\begin{array}{c}\text { Application } \\
\text { rate }\end{array}$ & $\begin{array}{c}\text { Soil } \\
\text { texture }\end{array}$ & $\begin{array}{l}\text { Organic } \\
\text { carbon }\end{array}$ & $\mathrm{N}$ & $\mathrm{P}$ & $\mathrm{K}$ & $\mathrm{pH}$ & CEC & Reference \\
\hline $\begin{array}{l}\text { Water hyacinth } \\
\text { compost }\end{array}$ & $0.25 \mathrm{~g} / \mathrm{kg}$ & NA & $12.5 \% \uparrow$ & NA & $116.6 \% \uparrow$ & $85.71 \% \uparrow$ & $6.70 \% \uparrow$ & NA & Muktamar et al. (2016) \\
\hline $\begin{array}{l}\text { Water Hyacinth } \\
\text { compost }\end{array}$ & $50 \mathrm{~g} / \mathrm{kg}$ & $\begin{array}{l}\text { Sandy } \\
\text { Loam }\end{array}$ & $73.46 \% \uparrow$ & $41.75 \% \downarrow$ & NA & NA & $0.80 \% \uparrow$ & $47.97 \% \uparrow$ & Khan and Sarwar (2002) \\
\hline Cattle manure & $20 \mathrm{~g} / \mathrm{kg}$ & $\begin{array}{c}\text { Sandy Clay } \\
\text { Loam }\end{array}$ & $35.39 \% \downarrow$ & $25 \% \uparrow$ & $4.83 \% \uparrow$ & $73.68 \% \uparrow$ & $2.75 \% \uparrow$ & $17.81 \% \uparrow$ & Ewulo (2005) \\
\hline Poultry manure & $20 \mathrm{~g} / \mathrm{kg}$ & $\begin{array}{c}\text { Sandy Clay } \\
\text { Loam }\end{array}$ & $46.54 \% \uparrow$ & $45.45 \% \uparrow$ & $5.625 \% \uparrow$ & $87.5 \% \uparrow$ & $5.66 \% \uparrow$ & $20.83 \% \uparrow$ & Ewulo (2005) \\
\hline $\begin{array}{l}\text { Water hyacinth } \\
\text { fertilizer }\end{array}$ & $0.45 \mathrm{~g} / \mathrm{kg}$ & NA & $28 \% \uparrow$ & $169.23 \% \uparrow$ & $99 \% \uparrow$ & $133.3 \% \uparrow$ & $12.50 \% \uparrow$ & $\uparrow 107.55 \% \uparrow$ & Gashamura (2009) \\
\hline
\end{tabular}

NA-Not available, $\uparrow$-increase, $\downarrow$-decrease. 
Potential of Water Hyacinth (Eichhornia crassipes) as Compost and its Effect on Soil and Plant Properties: A Review

Table 4: Effects of water hyacinth compost on physical growth parameters.

\begin{tabular}{lcccl}
\hline Growth attributes & Test crop & Dose of compost & $\begin{array}{c}\text { Percentage increase } \\
\text { compare to control }\end{array}$ & Reference \\
\hline Germination percentage & Wheat & Soil : compost1:1 & 144.4 & Vidya and Girish, (2014) \\
& Black gram & $1: 1$ & 6.3 & Sahana Sonter et al. (2018) \\
No of leaves & Okra & 5 tons / ha & 56.8 & Lekshmi and Viveka, (2011) \\
Shoot length $(\mathrm{cm})$ & Wheat & Soil : compost $1: 1$ & 17.7 & Vidya and Girish, (2014) \\
& Okra & 5 tons / ha & 40.4 & Lekshmi and Viveka, (2011) \\
& Black gram & $1: 1$ & 16.4 & Sahana Sonter et al. (2018) \\
Root length $(\mathrm{cm})$ & Wheat & $1: 1$ & 36.2 & Vidya and Girish, (2014) \\
Plant height $(\mathrm{cm})$ & Tomato & 74.1 tons /ha & 63.2 & Mashavira et al. (2015) \\
& Black gram & Soil : compost $1: 1$ & 16.4 & Sahana Sonter et al. (2018) \\
Root/shoot ratio $(\mathrm{cm})$ & Wheat & $1: 1$ & 15.7 & Vidya and Girish, (2014) \\
Biomass & Wheat & $1: 1$ & 205.5 & Vidya and Girish, (2014) \\
& Black gram & $1: 1$ & Sahana Sonter et al. (2018) \\
Shoot dry weight $(\mathrm{g})$ & Okra & 5 tons / ha & 22 & Lekshmi and Viveka, (2011) \\
& Common bean & $5000 \mathrm{~kg} /$ ha & 56 & Osoro et al. (2014) \\
Root dry weight & Maize & $5000 \mathrm{~kg} / \mathrm{ha}$ & 105.6 & Osoro et al. (2014) \\
& Okra & 5 tons / ha & 161.1 & Lekshmi and Viveka, (2011) \\
& Common bean & $5000 \mathrm{~kg} / \mathrm{ha}$ & 116 & Osoro et al. (2014) \\
\hline
\end{tabular}

fertilizers application in the past six planting seasons with application of compost fortified with cattle manure. Furthermore, an average yield of $68 \mathrm{t} / \mathrm{ha}$ was recorded in tomato at a rate of $74.1 \mathrm{t} / \mathrm{ha}$ water hyacinth compost application by Mashavira et al. (2015). The higher yield associated with water hyacinth compost might be due to the greater availability of nutrients especially $\mathrm{K}$ which is essential in water regulation in the plant and increases physical and physiological components of plant such as leaf area index, chlorophyll content. Potassium is also a key component in enzymic activities, carbohydrate metabolism and translocation, nitrogen metabolism and protein synthesis; therefore, it increases production and distribution of photosynthates leading to higher yields. Increasing $\mathrm{K}$ content is believed to improve the yield of tomato (fruit) crops (Hartz, 2001) as it is responsible for tomato growth vigor and it stimulates early flowering and fruit setting thereby increasing the number of tomato fruits per plant and thus increasing yield. These findings clearly imply that water hyacinth compost has greater effect on yield of all categories of crops inclusive of cereals, legumes and vegetables as well.

\section{Challenges in utilization of water hyacinth}

Even though compost making is a possible mean for controlling the aggressive growth of water hyacinth in water bodies and application of this organic manure results several benefits in soil properties, but in practical this mean of water hyacinth control has some challenges. Longer time consumption, difficulties in water hyacinth harvesting, higher labour cost, chances for accumulation of heavy metals in plant tissues, less awareness and less skilled personals involvement are some of the mentionable. Here, the possible means to minimize these challenges are discussed.
Collection of water hyacinth for its utilization is the foremost challenge. In most developing countries water hyacinth harvesting is done manually in which aquatic weeds are removed from the water surface with the help of hands Therefore, manual reaping is labor-intensive work, with high energy and low proficiency and inefficient in huge lakes or water bodies. In addition, it consumes more time (Cerveira Junior and Carvalho et al. 2019) and may cause injuries to human with the aquatic fauna. These drawbacks can be minimized with mechanical harvesting for which mechanical mowers, destroyer boats, mechanized dredgers, weed harvester tractors and crusher boats are used to collect the weeds from water bodies. However, the initial capital cost is relatively high in this method of harvesting.

Water hyacinth being a plant biomass is primarily composed of three constituents such as lignin, cellulose and hemicellulose that are hardly available for microorganisms during decomposition of organic manure. The lignocellulose is the major organic compound that restrict the rate of composting of agricultural and forestry waste, among which the lignin acts as a major supplier of speed limiting compound (Patel et al. 1993). Therefore, to attain good quality water hyacinth compost in a shorter time period, it is necessary to speed up the degradation of lignin, cellulose and hemicelluloses during the composting process. Inoculation of water hyacinth with external lignin degrader, use of rotary drum for composting are available possible means to fasten the degradation of water hyacinth. Rotary drum composting provides high-rate composting due to appropriate mixing of composting materials and higher thermophilic temperature (Singh and Kalamdhad et al. 2014).

Water hyacinth is a well-known cleaner of pollutants, especially effective for removal of heavy metals. Therefore, 
Potential of Water Hyacinth (Eichhornia crassipes) as Compost and its Effect on Soil and Plant Properties: A Review

a question remains that there are chances for accumulation of absorbed heavy metals into plant tissues when use water hyacinth for compost making. In this context, rate of application influences accumulation of heavy metals. Mashavira et al. (2015) reported that accumulation of heavy metals $(\mathrm{Pb}, \mathrm{Cu}$ and $\mathrm{Zn}$ ) was less than Codex Alimentarious Commission permissible level and recommended application of water hyacinth compost at a rate of $74 \mathrm{t} / \mathrm{ha}$ for increased tomato yield without heavy metal toxicity to consumers. However, in general water hyacinth roots absorb more heavy metals than the shoots and these roots and rhizomes can be excluded in compost making as frontline prevention of minimizing accumulation of heavy metals. On the other hand, powdered water hyacinth can be made into slurry and allowed for fermentation for a period of three months to reduce the heavy metal concentration (So et al. 2003; Sanni and Adesina, 2012). Hence, sullied rhizomes and roots of water hyacinth can be dried into ash and heavy metals could be separated and reused (Jadia, 2009).

Loses of nutrients primarily nitrogen, potassium through leaching (Guo et al. 2012; Goyal et al. 2005, Masaka and Ndhlovu, 2007) and denitrification (Prasad et al. 2013) during composting is another challenge associated with. The loss of nutrient delays composting maturity (Osoro et al. 2014; Lata and Veenapani, 2011; Seoudi, 2013) and decreases the quality of compost produced. Therefore, composting water hyacinth with materials like poultry manure, cattle manure, molasses and effective microorganisms can also help to reduce nutrient losses as well as hasten the decomposition process (Sylvia et al. 2005).

\section{SUMmARY AND FUTURE PROSPECTS}

Water hyacinth is considered as the world's worst aquatic weed as it causes environmental degradation due to their vigorous growth and unique characteristics. Increased agricultural runoff into water bodies has resulted in a rise in nutrient concentrations, causing turbidity and a drop in dissolved oxygen. This has resulted in algae blooms, waterweed infestations, fish mortality and water-borne infections. The usage of water hyacinth compost reduces the amount of chemical fertilizers and organic fertilizers required, lowering both costs and pollution. To eradicate its negative impact on ecosystems, make use of them is found as best alternative. Water hyacinth has a great potential in soil fertility management as a slow release organic fertilizer via composting. Water hyacinth compost as having greater amount of organic matter it plays significant role in improvement of soil physical, chemical and biological properties which in turn make available nutrients that are required for plant growth and development hence leads to considerably higher growth parameters and yields. Findings got so far on effects of water hyacinth compost are limited to mainly sandy loam soil textures and annuals. Therefore, in future, studies can be expanded to explore the effects of water hyacinth in other textured soils as well as perennials.
Hence, though water hyacinth is a good source of alternative for inorganic fertilizers in soil nutrient management no any studies have done yet on the potential of water hyacinth to be utilized as liquid fertilizer and its effect on physical and physiological parameters of crops and soil properties. So that, in future, with the knowledge and idea obtained from this review younger generation may focus this scope as well. Moreover people are less aware about potential of water hyacinth as nutrient source and the gap can be reduced with awareness programmes.

\section{REFERENCES}

Abdalla, M.A. and Elballah, M.M.A (2015). Utilization of composted bagasse, water hyacinth and banana waste in reclamation of desert soils. DCG Report No. 76.

Abdelsabour, M. F. (2010). Water hyacinth: available and renewable resource. Electronic Journal of Environmental Agriculture and Food Chemistry. 9(11): 1746-1759.

Agbede, T. M., Ojeniyi, S. O., and Adeyemo, A. J. (2008). Effect of poultry manure on soil physical and chemical properties, growth and grain yield of sorghum in southwest, Nigeria. American-Eurasian Journal of Sustainable Agriculture. 2(1): $72-77$.

Azam, F., Malik, K.A. and Sajjad, M.I. (1985). Transformations in soil and availability to plants of $15 \mathrm{~N}$ applied as inorganic fertilizer and legume residues. Plant and Soil. 86: 3-13. http://dx.doi.org/10.1007/BF02185020.

Balasubramanian, D., Arunachalam, K., Arunachalam, A. and Das, A.K. (2013). Effect of water hyacinth (Eichhornia crassipes) mulch on soil microbial properties in lowland rainfed ricebased agricultural system in northeast India. Agric Res. 2(3): 246-257. DOI 10.1007/s40003-013-0073-7.

Basak, M.N. (1948). Water Hyacinth Compost. Alipore, West Bengal Govt. Press.

Bates, R.P. and Hentges, J.F. (1976). Aquatic weeds - eradicate or cultivate? Economic Botany. 30(1): 39-50.

Beesigamukama, D., Tumuhairwe, J.B., Muoma, J., John M. Maingi, Ombori, O., Mukaminega, D., Nakanwagi, J. and Amoding, A. (2018). Improving water hyacinth-based compost for crop production. Journal of Agricultural Science and Food Technology. 4(3): 52-63.

Burton, J., van Oosterhout, E., Ensbey, R. and Julien, M. (2010). Water hyacinth (Eichhornia crassipes): Weed of National Significance. Department of Primary Industries, NSW., Australia.

Cerveira Junior W.R., Carvalho L.B. (2019). Control of water hyacinth: A short review. Communications in Plant Sciences. 9(1): 129-132. doi: 10.26814/cps2019021.

Chang, J.I., Chen, Y.J. (2010). Effects of bulking agents on food waste composting. Bioresource Technology. 101: 59175924. DOI: 10.3923/ja.2002.64.65.

Dhal, G.C., Singh, W.R., Khwairakpam, M. and Kalamdhad, A.S. (2012). Composting of water hyacinth using Saw dust/ Rice straw as a bulking agent. International Journal of Environmental Sciences. 2(3): 1223-1238.

Ewulo, B.S. (2005). Effect of poultry dung and cattle manure on chemical properties of clay and sandy clay loam soil. Journal of Animal and Veterinary Advances. 4(10): 839841. 
Potential of Water Hyacinth (Eichhornia crassipes) as Compost and its Effect on Soil and Plant Properties: A Review

Gashamura, F.R. (2009). Effects of manure from water hyacinth on soil fertility and maize performance under controlled conditions in Rwanda. International Master Programme at the Swedish Biodiversity Centre.

Goldhamer, D.A., Grimes, D.W., Culick, S.H., Munk, D.S. (1994). Cover cropped enhanced water infiltration of a slowly permeable fine sandy loam. Soil Sci. Soc. Am. J. 58.

Goyal, S., Dhull, S.K., Kapoor, K.K. (2005). Chemical and biological changes during composting of different organic wastes and assessment of compost maturity. Bioresource Technology. 96(14): 1584-1591.

Gunnarsson, C.C. and Petersen, C.M. (2007). Water Hyacinths as a resource in agriculture and energy production: $\mathrm{A}$ Literature Review. Waste Management. 27: 117-129. http://dx.doi.org/10.1016/j.wasman.2005.12.011

Guo, R., Li, G., Jiang, T., Schuchardt, F., Chen, T., Zhao, Y. and Shen, Y. (2012). Effect of aeration rate, $\mathrm{C} / \mathrm{N}$ ratio and moisture content on the stability and maturity of compost. Bioresource Technology. 112: 171-178.

Gupta, M., Sarmah, R. and Gupta, S. (2004). Nutrient composition of Pleurotus sajorcaju grown on different substrates. Journal of Food Science and Technology. 41: 504-586.

Hartz, T.K., Miyao, E.M., Mullen, R.J. and Cahn, M.D. (2001). Potassium fertilization effects on processing tomato yield and fruit quality. Acta Horticulturae. 542: 127-133.

Hassen, A., Belguith, K., Jedidi, N., Cherif, M. and Boudabous, A. (2001). Microbial characterization during composting of municipal solid waste. Bioresource Technology. 80: 217225. doi:10.1016/S0960-8524(01)00065-7.

Hawkesford, M., Horst, W., Kichey, T., Lambers, H., Schjoerring, J., Møller, I.S. and White, P. (2012). Functions of Macronutrients. In: Marschner's Mineral Nutrition of Higher Plants Academic Press. (pp. 135-189).

Haynes, R.J. (2000). Labile organic matter as an indicator of organic matter quality in arable and pastoral soils in New Zealand. Soil Biology and Biochemistry. 32(2): 211-219.

Jadia, C.D. and Fulekar, M.H. (2009). Phytoremediation of heavy metals: Recent techniques. African Journal of Biotechnology. 8: 921-928.

Jafari, N. (2010). Ecological and socio-economic utilization of water hyacinth [Eichhornia crassipes (Mart) Solms]. Journal of Applied Science and Environmental Managment. 14: 4349. doi: 10.4314/jasem.v14i2.57834.

Khan, S. and Sarwar, K.S. (2002). Effect of water-hyacinth compost on physical, physico-chemical properties of soil and on rice yield. Journal of Agronomy. 1: 64-65. http://dx.doi.org/ 10.3923/ja.2002.64.65.

Kwabiah, A.B., Stoskopf, N.C., Palm, C.A., Voroney, R.P., Rao, M.R., Gacheru, E. (2003). Phosphorus availability and maize response to organic and inorganic fertilizer inputs in a short-term study in Western Kenya. Agricultural Ecosystems and Environment. 95: 49-59.

Lata, N. and Veenapani, D. (2011). Response of water hyacinth manure on growth attributes and yield in Brassica Juncea. Journal of Central European Agriculture. 12(2): 336-343.

Lekshmi, N.C.J.P. and Viveka, S. (2011). Hyacinth compost as a source of nutrient for Abelmoschus esculentus. Indian Journal of Science and Technology. 4(3): 236-239.
Lickacz, J. and Penny, D. (2001). Soil Organic Matter: Agriculture and Rural Development. Government of Alberta, Plant Industry Division, Alberta.

Malik, A. (2007). Environmental challenge vis a vis opportunity: The case of water hyacinth. Environment International. 33: 122-138. http://dx.doi.org/10.1016/j.envint.2006.08. 004.

Martin, J.P., Martin, W.P., Page, J.B., Raney, W.A. and De Ment, J.D. (1955). Soil Aggregation. In: Advances in Agronomy Academic Press. (Vol. 7, pp. 1-37).

Masaka, J. and Ndhlovu, S. (2007). The effect of different forms of water hyacinth (Eichchornia crassipes) organic fertilizers on leaf growth rate and yield of Rape (Brascica napus). International Journal of Agricultural Research. 2(3): 254260.

Mashavira, M., Chitata, T., Mhindu, R. L., Muzemu, S., Kapenzi, A and Manjeru, P. (2015). The Effect of water hyacinth (Eichhornia crassipes) compost on tomato (Lycopersicon esculentum) growth attributes, yield potential and heavy metal levels. American Journal of Plant Sciences. 6: 545553. http://dx.doi.org/10.4236/ajps.2015.64059.

Mathur, A., Mathur, S.K, Singh, A.B. and Subbara, A. (2016). Production of Enriched Compost from Water hyacinth (Eichorina crassipes). An International E-Journal on Emerging Trends in Science, Technology and Management. 1(4): 26-31.

Muktamar, Z., Justisia B. and Setyowati, N. (2016). Quality enhancement of humid tropical soils after application of water hyacinth (Eichornia crassipes) compost. Journal of Agricultural Technology. 12(7.1): 1211-1227.

Naluyange, V., Ochieno, D.M.W., Maingi, J.M., Ombori, O., Mukaminega, D., Amoding, A., Odendo, M., Okoth, S.A., Shivoga, W.A. and Muoma, J.V.O. (2014). Compatibility of Rhizobium inoculant and water hyacinth compost formulations in Rosecoco bean and consequences on Aphis fabae and Colletotrichum lindemuthianum infestations. Applied Soil Ecology. 76: 68-77. https://doi.org/10.1016/j.apsoil.2013. 12.011.

Nasrin, A., Khanom, S. and Hossain, S.A. (2019). Effects of vermicompost and compost on soil properties and growth and yield of Kalmi (Ipomoea aquatica Forsk.) in mixed soil. Dhaka University Journal of Biological Sciences. 28(1): 121-129.

Olupot, G., Etiang, J., Ssali, H., Nahasirye, M. (2004). Sorghum yield response to Kraal manure combined with mineral fertilizers in Eastern Uganda. Muarik Bulletin. 7: 30-37.

Opande, G.O., Onyango, J.C., Wagai, S.O. (2004). Lake Victoria: The water hyacinth [Eichhornia crassipes (Mart.) Solms], its socio-economic effects, control measures and resurgence in the Winam gulf. Limnologica. 34(1-2): 105109.

Oroka, F.O. (2013). Influence of water hyacinth-based vermicompost and cassava -groundnut intercropping on some physical properties of a tropical soil. Journal of Natural Sciences Research. 3(7): 155-182.

Osoro, N.P., Fanuel Kawaka, Naluyange, V., Ombori, O., John O. Muomc, Alice Amoding, Mukaminega, D., Morris Muthini and John M. Maingi. (2014). Effects of water hyacinth [Eichhornia crassipes (Mart.) solms] compost on growth and yield of common beans (Phaseolus vulgaris) in Lake Victoria Basin. European International Journal of Science and Technology. 3(7): 173-186. 
Osoro, N., John O. Muoma, Alice Amoding, Mukaminega, D., Muthini, M., Ombori, O. and John M. Maingi. (2014). Effects of water hyacinth [Eichhornia crassipes (Mart.) solms] compost on growth and yield parameters of maize (Zea mays). British Journal of Applied Science and Technology. 4(4): 617-633.

Patel, V.B., Patel, A.R., Patel, M.C. and Madamwar, D.B. (1993). Effect of metals on anaerobic digestion of water hyacinthcattle dung. Applied Biochemistry and Biotechnology. 4345-50.

Prasad, R., Singh, J. and Kalamdhad, A.S. (2013). Assessment of nutrients and stability parameters during composting of water hyacinth mixed with cattle manure and sawdust. Research Journal of Chemical Sciences. 3(4): 70-77.

Rashid, G.H. and Iftekhar, U.A. (1992). Effect of added organic matter on some physical and physicochemical properties of a sandy loam soil. Proceeding of the Seminar on Research Findings in Some Biotechnological Aspects. 1: 45-48.

Rodrigues, A.J., Oderob, M.O., Hayombe, P.O., Akunod,W., Kerich, D. and Maobe, I. (2014). Converting water hyacinth to briquettes: A beach community based approach. International Journal of Sciences: Basic and Applied Research. 15(1): 358-378.

Ryckeboer, J., Mergaert, J., Vaes, K., Klammer, S., De Clercq, D., Coosemans, J., Insam, H. and Swings, J. (2003). A survey of bacteria and fungi occurring during composting and self-heating processes. Annal of Microbiology. 53: 349410.

Sanni, K.O. and Adesina, J.M. (2012) Utilization of water hyacinth (Eichhornia crassipies) as liquid fertilizer on the growth and yield of fluted pumpkin (Telfairia occidentalis). South Asian Journal of Experimental Biology (in press).

Seoudi, O.A. (2013). Utilization of water hyacinth and banana wastes compost in reclamation of sandy soils for increasing growth, yield of cowpea. Journal of Advanced Laboratory Research in Biology. 4(1): 36-45.

Sindhu, R., Binod, P. and Pandey, A. (2017). Water hyacinth a potential source for value addition: an overview. Bioresource Technology. 230: 152-162.
Singh, A. and Sharma, S. (2002). Composting of a crop residue through treatment with microorganisms and subsequent vermicomposting. Bioresource Technology. 85: 107-111.

Singh, J. and Kalamdhad, A.S. (2014). Influences of natural zeolite on speciation of heavy metals during rotary drum composting of green waste. Chem Speciation and Bioavailability. 26(2): 1-11.

So, L. M., Chu, L.M. and Wong, P.K. (2003). Microbial enhancement of $\mathrm{Cu}^{2+}$ removal capacity of Eichhornia crassipes (Mart). Chemosphere. 52: 1499-1503.

Sonter, S., Pramod V. Pattar, Ramalingappa. (2018). Effect of Eichhornia crassipes (Mart.) Solms. compost on morpho-physiological parameters of black gram [Vigna mungo (L.) Hepper]. International Journal of Science and Healthcare Research. 3(4): 20-26.

Sultani, M.I., Gill, M.A., Anwar, M.M. and Athar, M. (2007). Evaluation of soil physical properties as influenced by various green manuring legumes and phosphorus fertilization under rain fed conditions. International Journal of environmental Science and Technology. 4(1): 109-118.

Sylvia, D.M., Hartel, P.G., Fuhrmann, J.F. and Zuberer, D.A. (2005). Principles and Applications of Soil Microbiology. $2^{\text {nd }}$ edition. Pearson Prentice Hall.

Vidya, S. and Girish, I. (2014). Water hyacinth as a green manure for organic farming. International Journal of Research in Applied Natural and Social Sciences. 2(6): 65-72.

Wanas, S.A. (2006). Towards proper management of clayey soils: II. Combined effects of ploughing and compost on soil physical properties and corn production. Journal of Applied Sciences Research. 2(3): 123-128.

Wasonga, C.J., Sigunga D.O. and Musandu, A.O. (2008). Phosphorus requirements by maize varieties in different soil types of Western Kenya. African Crop Science Journal. 16(2): 161-173.

Wilson, J.R. and Holst, N., Rees, M. (2005). Determinants and patterns of population growth in water hyacinth. Aquatic Botany. 81: 51-67.

Woomer, P.L., Muzira, R., Bwamiki, D., Mutetikka, D., Amoding, A. and Bekunda, M.A. (2000). Biological Management of water hyacinth waste in Uganda. Biological Agriculture and Horticulture. 17: 181-196. 